\title{
Participation Profiles of Adult Undergraduate Students in Turkey
}

\author{
Türkiye'deki Yetişkin Lisans Öğrencilerinin Katılım Profilleri
}

\author{
Emine ARUĞASLAN, Meral UYSAL
}

\begin{abstract}
In recent years, the profile of the student population in higher education has changed and the number of adult students has begun to increase gradually. Considering this change, the need for a comprehensive examination of adult students having undergraduate education in Turkey has arisen. For this reason, this study has been conducted to determine participation dynamics of adult students who decided to take formal undergraduate education at the age of 25 or older in Turkey. In research, firstly, existing higher education policies and practices for adult students have been investigated. Then, in a research group, participation patterns of adult undergraduate students have been examined. The data used in this study was collected from 472 participants in a study group. Participation characteristics such as the reasons for participation, barriers to participation, program preference reasons of adults were investgated in the context of higher education.
\end{abstract}

Keywords: Lifelong learning, Higher education, Undergraduate education, Adult student, Nontraditional student

\section{ÖZ}

Son yıllarda, yükseköğretimdeki öğrenci nüfusunun profili değişmiş ve yetişkin öğrenci sayısı giderek artmaya başlamıştır. Bu değişim göz önünde bulundurulduğunda, Türkiye’de lisans eğitimi alan yetişkin öğrencilerin kapsamlı bir şekilde incelenmesi ihtiyacı doğmuştur. Bu nedenle bu çalışma, Türkiye’de 25 yaş ve üzerinde örgün lisans eğitimi almaya karar veren yetişkin öğrencilerin katılım dinamiklerini belirlemek amacıyla yapılmıştır. Araştırmada öncelikle yetişkin öğrenciler için mevcut yüksek öğrenim politikaları ve uygulamaları değerlendirilmiştir. Daha sonra bir araştırma grubu üzerinde yetişkin lisans öğrencilerinin katılım örüntüleri incelenmiştir. Araştırma, bir çalışma grubundan toplanan 472 geçerli veri ile yürütülmüştür. Yetişkinlerin katılım nedenleri, katılım engelleri, program tercih nedenleri gibi katılım özellikleri yüksek öğretim kapsamında incelenmiştir.

Anahtar Sözcükler: Yaşam boyu öğrenme, Yükseköğretim, Lisans eğitimi, Yetişkin öğrenci, Geleneksel olmayan öğrenci

\section{INTRODUCTION}

In the past centuries, while the education that people received at school age was sufficient in their personal and professional lives, we can say that this situation is changing nowadays. As a result of factors such as technological developments, transition to information society, global competition, prolonged human life, people have become lifelong learners.

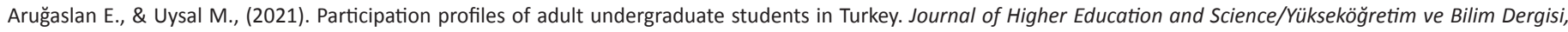
11(2), 313-327. https://doi.org/10.5961/jhes.2021.451

Emine ARUĞASLAN (-)

ORCID ID: 0000-0002-8153-9117

Isparta University of Applied Sciences, Distance Learning Vocational School, Isparta, Turkey

Isparta Uygulamalı Bilimler Üniversitesi, Uzaktan Eğitim Meslek Yüksekokulu, Isparta, Türkiye

eminearugaslan@isparta.edu.tr

Meral UYSAL

ORCID ID: 0000-0002-8443-6375

Ankara University, Faculty of Education, Department of Educational Sciences, Lifelong Learning and Adult Education, Ankara, Turkey

Ankara Üniversitesi, Eğitim Fakültesi, Eğitim Bilimleri Bölümü, Hayat Boyu Öğrenme ve Yetişkin Eğitimi, Ankara, Türkiye 
When the concepts of adult education, lifelong education and lifelong learning are examined globally, it can be said that these concepts are intertwined. Adult education is seen as an integral part of lifelong learning and in this context, all activities planned for adult education serve lifelong learning. In the 1970s, "Lifelong Education" was an inclusive concept of individuals who had to leave formal education or who did not have educational opportunities. After the 1990s, it has evolved into "Lifelong Learning" in the economic discourse of the labor market and / or international actors (Kaya, 2010).

Lifelong learning, while on one hand, emphasizes motivating all individuals to learn throughout all their lives from their childhood to older ages, on the other hand it provides all adults, actively working or not, with opportunities to enroll back in education and update their skills and knowledge (Eurydice, 2000). Participation rates are increasing across all races, ethnic groups, and levels of education; for part-time and full-time employees, for unemployed and retired, and for most labor and age groups (Creighton \& Hodson, 2002). Within the context of lifelong learning, it is important that adults have access to education as much as individuals in all age groups. Thus, it can be said that higher education institutions accepted as the last step in formal education, have a vital role in realizing certain needs and expectations of adults.

Though adult students have been described as "nontraditional" in studies conducted on higher education, other studies have mentioned that 25 years of age or older students constitute almost half of those who enrolled in higher education (eg, CAEL, 1999; Choy \& Premo, 1995; Coulter \& Mandell, 2012; Stein, Wanstreet, \& Trinko, 2011). Taking into account the changing population graph all over the world, it can be said that participation of adults in higher education will further increase in the following years.

Increasing participation status of adult students in higher education appears in concrete form when it comes to university exam rankings, in libraries, classrooms and their appearance in educational news. Striking headlines are set for news on adults who return to or begin university after a certain age, and are shared in educational portals. News such as "The professor became a student at the faculty where she taught" (Memurlar.Net, 2020) and "Never too old for school: At 96, man from Japan becomes oldest university graduate" (Firstpost, 2016) prove that adults are not traditional university students.

With the aging population, it can be said that adults in Europe and in our country will have more participation in higher education in the following years. In 2050, the population in Turkey is estimated to be 93,475,575 millions (TUIK, 2013a). Turkey will reach its peak in 2050 and then the population will decrease and the average age will rise to 35 . Hence, it can be said that the demographic characteristics of individuals who will participate in higher education will differ with this change. While it is observed that the participation rates of the students of traditional age are decreasing, it can be predicted that the participation rates of non-traditional students will increase gradually.
Considering all these developments related to changing population projection in higher education, there is no comprehensive study of adults in higher education in Turkey. This study, which may fulfill the need, aims to construct detailed participation profiles of adults in higher education.

It will not be right to limit the studies on adults in higher education to a single country. It is important to evaluate each country in its own culture and to compare it with other countries. Especially the development of constructive policies in relation to adults is on the education agenda in many countries around the world. In this context, scientists analyze these issues in depth.

\section{Nontraditional Student}

Adults who participate in educational activities possess certain characteristics that are easily distinguishable from those of students at the traditional age (Kasworm, 2003). These characteristics may vary depending on the age at which participation is taking place, level of education, gap in education, personal experience, and reasons for participation. The term 'adult student' refers to those associated with learning experiences at age 25 or older (Allen, 1993; Compton, Cox \& Laanan, 2006; Jung \& Cervero, 2002; Lake \& Pushchak, 2007; Myers, Conte \& Rubenson, 2014; Malhotra, 1997), generally under 40 years (Johnstone, 1963), who have taken at least a two year break in their education (Boeren, Holford, Nicaise \& Baert, 2012; Saar, Vöörmann \& Lang, 2014), possess an above average income (Jung \& Cervero, 2002), are a full-time worker, part-time student, and usually married with children (Fairchild, 2003; Graham \& Donaldson, 1999; Kwang, Hagedorn, Williamson \& Chapman, 2004). Besides, most adult students are financially independent (Banks, 2010; Kasworm, 2003; Lake \& Pushchak, 2007; Bundy \& Smith, 2004), and have occupational and domestic responsibilities (CAEL, 1999; Caruth, 2013; Chao, DeRocco \& Flynn, 2007; Kwong, Mok \& Kwong, 1997; Rabourn, Shoup \& Brckalorenz, 2015). When studies conducted on participation profiles are examined, it is found that adult students carry at least one of the above characteristics.

\section{Adults in Higher Education}

Much like primary and secondary education, adult education is a comprehensive and amorphous field of application in higher education without proper boundaries such as age (Merriam \& Caffarella, 2001). 25 years of age was generally accepted as the age limit in many studies on nontraditional students in higher education (Bengo, 2020; Caruth, 2013; Compton et al., 2006; Kasworm, 2010; Lin, 2016; Lopuch, 2015; Saar et al., 2014; Schuetze \& Slowey, 2002; Wallace, 1989). It can also be considered that the majority of students attending higher education have reached adulthood. However, common perception is that this group, which referred to as adult students, represents those who are older than typical students and have decided to re-participate in formal education after a certain time spent out of education system (Eurydice, 2011). The table below shows the comparison between traditional and nontraditional adult students which is made by the researchers of this study. 
Table 1: Comparison of Traditional and Nontraditional Students in Higher Education

\begin{tabular}{l|c|c}
\hline Characteristics & Traditional Student & Nontraditional Student \\
\hline Age & $18-22$ & $>25$ \\
Financial Dependence & Mostly dependent & Mostly independent \\
\hline Financial Aid & Mostly get financial support & Rarely get financial support \\
Enrollment Type & Mostly full-time student & Mostly part-time student \\
\hline Working Status & Mostly unemployed or work part time & Mostly work full-time \\
\hline Marital Status & Mostly single & Mostly married \\
\hline Parental Status & Rarely parents & Mostly parents \\
\hline Consultant Support & Mostly get counselor support & Rarely get counselor support \\
\hline Participation Reason & Primarily finding a job & There can be many reasons \\
Social Relations in Campus & Mostly spend time with their peers on campus & Mostly spend time with their parents outside \\
Life Experiences & Limpus
\end{tabular}

\section{Research on Adults in Higher Education}

Reasons such as changing life experiences and extension of life span called 'youth' have altered age distribution of student population in undergraduate programs (Bye, Pushkar \& Conway, 2007). Increasing participation rates of adults in higher education have encouraged researchers to study in this area. In this context, initial research conducted on adults in higher education have been participants' profiles and reasons for participation.

Grabowski (1972) examined the relationship between the reasons of participation of adults and demographic characteristics such as gender, age, marital status, income level, employment type, past university experiences in his study at higher education. The "Reasons for Participation in Education" scale developed by Burgess was revised by Grabowski in 1972 and applied to 180 undergraduate students and a seven-factor result was obtained. These factors are; the desire to know, the desire to achieve individual goals, the desire to take part in social activities, the desire to achieve social goals, the desire to escape, the desire to work alone, the desire for intellectual trust.

Morstain and Smart (1977) developed a typological framework on the motivations of part-time enrolled adult learners at the university (college) in the USA using the "Education Participation Scale" developed by Boshier and collected the data in six factors. These factors are; social relations, external expectations, social welfare, professional development, escape / stimulation, and conscious interest factors.

Kasworm (1990) conducted his study using the method of meta-analysis on adults with undergraduate education in American higher education. In this study, it aimed to determine the basic perceptual assumptions and orientations of adult students regarding past higher education practices. Kasworm has identified five inductive thematic categories. The first of these is "deficiency". The low academic performance of adults is generally mentioned here. The second of themes is "student input and adaptation". Kasworm identified factors affecting university-specific entry and adaptation for adult students. He also emphasized the view that public policies that will improve the effective university structure and process of adults will raise awareness. Another theme, "definition and qualification", explained the idea of adult students at a descriptive level. In terms of theoretical interdisciplinary frameworks with the theme of "psychosocial development", he examined the psychosocial adjustment characteristics of adult students and the specific effects of responsibilities and conflicts in the role of adult students (individual, family, professional). In the theme of "equality and output", he evaluated the equality and output problems of undergraduate education for adults.

Another research topic including adults in higher education is the comparison of traditional-age and adult students. Choy and Premo (1995) defined demographic and socio-economic characteristics of adult students aged 24 and over in higher education. They also compared the patterns of participation of adult students, how they combine working and reading, and the amount of economic support they received, compared with students of traditional age. Researchers stated that the participation rate of adult students in the higher education institution in 1970 increased from $28 \%$ to $45 \%$ according to 1991 data. Working adults 24 years of age and older have started education for purposes such as "gaining new skills for better work", "expanding new job options" and "developing knowledge and skills".

Graham and Donaldson (1999) studied the impact of universities for the academic and intellectual development of traditional age students and adult students at college and university levels, such as private, technical, two-year and four-year, in various geographic regions in the United States. In the study, statements related to academic and intellectual interest were directed to the participants and the results were reported. In this context, it has been observed that adults score the same or higher than traditional students.

Rabourn et al. (2015) conducted a study to determine specific characteristics of adult students in higher education and to as- 
sess how they differ from traditional-age students. Adult learners are described as a group that shows more interest in education in academic terms, and communicates less with peers and faculty members. Adult learners stated that they found their institutions less supportive in terms of their learning and development. Berker and Horn (2003) compared two groups of 24 years and older adolescents enrolled in post-secondary undergraduate education by asking whether they were "a student working to meet their expenses" or "an employee who decided to enroll in school." While the "student who work" mostly participate in education in professional fields; it was observed that those "employees who study" were mostly registered in social / behavioral sciences.

Roddy (2005) examined whether or not expectations of adults at age 25 and older who returned to undergraduate education or enrolled in it or for the first time were met through educational outcomes. According to the results of the study, it was observed that the vast majority of adults returned to education to achieve their career and job-related goals. With the assertion that adult undergraduate students are not represented sufficiently in academic studies, Donaldson and Townsend (2007) examined seven peer-reviewed journals in the USA covering adult undergraduate students. As a result of the study, it was revealed that only $41(1.27 \%)$ out of 3219 studies in total included adult undergraduate students.

Pollard (2008) examined perceptions of higher education for adults aged between 22 and 55, who worked mostly in labor market and were employed and are actively seeking jobs to a lesser extent. When the participants were asked about their participation in higher education in the future; While $30 \%$ stated that they would go to university in the future, $38 \%$ stated that this situation was not possible and the remaining $32 \%$ stated that they were not interested in this issue. Elliot and Brna (2009) investigated key factors behind the decision of students at a non-traditional age to continue their education. The five most important reasons of those determined to receive education are; development of skills and knowledge, personal success, increasing employment prospects, the desire to learn more about the chosen area, and higher salary.

Hefler and Markowitsch (2010) developed a typology appropriate to the participant model to deepen the understanding of participation in adult education, the role of education in living space, and the relationship between current workplaces and education programs. McAllister (2010) conducted a study of educational gerontology in Scotland, focusing on higher education participants aged 50 and over. McAllister stated that adult students in this profile are considered a marginal group with poor representation in the education system and should be supported in recruitment.

Based on interviews with national and international sources, policy makers and academics, Broek and Hake (2012) have established an analytical framework for policies and practices aimed at increasing higher education participation of adults in different countries who have not entered into higher education immediately or have left compulsory education after 18 years of age. It is stated in short-term policies that many issues need to be addressed, such as "What is the primary goal in increasing participation?". In the long term, it is stated that in order to deal with the problems faced by the aging society, it is necessary to rethink higher education in a lifelong learning perspective and the existing system also needs a basic revision.

DiSilvestro (2013) characterized adults as "golden opportunities" for higher education institutions, according to changing and developing population scales and changing age average. Based on this belief, he examined three higher education institutions succeeded against the challenges that older adults may encounter in higher education. In the study, it was pointed out that these institutions not only offer educational activities that include different course options, study groups, evening classes, summer classes, but also include social activities. Pos$\tan (2014)$ focused on universities in Moldova and educational opportunities they offered to adult students. Prins, Kassab and Campbell (2015) identified urban-rural differences by providing a comprehensive description of the demographic, financial, and educational characteristics of adults received post-secondary education in Pennsylvania.

In their study, Santos and Miguel (2020) investigated the enrollment status of non-traditional, returning, evening and adult (NTREA) students to distance education programs in higher education. This study examines the experiences of students studying in civil engineering, computer engineering, environmental engineering, chemical engineering, biomedical engineering at private universities in California. The results of the study are believed to guide many stakeholders such as NTREA students, university administration, and policy makers.

Venegas-Muggli (2020), examined the role of socio-demographic characteristics of non-traditional first-year university students in Chile on dropout rates. The results show that students who are working parents are more likely to drop out of higher education in the first year of their education.

Higher Education Policies and Practices Aimed at Adults in Turkey

Higher Education Council (YÖK) is at the top of the higher education system in Turkey. According to data submitted by YÖK, there are 185 universities within Turkey as of February 2018. Based on this number, increasing number of programs and quotas in these universities can be considered as regulations that increase the likelihood of being enrolled in a program that adults, as well as traditional students, have chosen.

In order to enter into a higher education program in Turkey, it is mandatory to take exams which the Evaluation, Selection and Placement Center (ÖSYM) administers. Within the exams of ÖSYM, there are also those allowing adults to enter into undergraduate education. One of these examinations is "Vertical Transfer Examination (DGS)". In this examination, an individual who has completed his/her associate degree education is placed in a division he/she chooses according to the quota and points of the related program and his/her score. Another exam is "Engineering Completion Programs Entrance Examination 
for Technical Teachers". If an adult who has earned the title of technical teacher or has graduated is to pass this examination, he/she is entitled to take the title of engineer if he/she completes the course curriculum in his/her field within a specified period. Another exam is "Program to Complete Bachelor in the Health Field". Entrance to these programs is based on the associate's graduation notes. Another policy and practice accelerating the return of high school-dropout adults to education are "Amnesty Laws". Adults not in the traditional age range also have "student amnesty laws", such as Law 6111 and 6353 (YÖK, 2017), to ensure their return to university education. Another practice is the "Second University" application, which offers the opportunity to receive education by enrolling in associate or undergraduate programs of Open Education, Economics and Business Administration faculties.

Higher education policies and practices held for adults in Turkey generally target traditional students or academic/administrative staff. Policies to support participation of adults in higher education programs and facilitate educational process are not sufficient to meet expectations. In Turkey, the prerequisite to enter a university is to have a high school diploma. Likewise, when an adult want to study in higher education, they attend the same exam as high school students and are placed in a program. To be admitted to an undergraduate program might be a challenging experience for many adults. For example, a 45-year-old individual who has family and career responsibilities and an 18-year-old who has recently graduated from the high school will be tested on the same terms and conditions when they want to enter the same program.

The tables regarding the number of newly registered students and the total number of students are shared by YÖK for each academic year. The researchers of the present study analyzed the data they obtained from these tables and formed Figure 1, Figure 2, Figure 3 and Figure 4. Taking the aging population into account, it is possible to say that the number of traditional-age students in higher education will gradually decrease over years, while it will increase for nontraditional adult students ( 25 years and over) (Figure 1).

In Figure 2, where the participation numbers of women and men enrolled at 25 years and older are given, the number of men participating in undergraduate education is constantly higher than that of women. In general, the number of women participants has increased almost every year.

When data in Figure 3 is examined, it is seen that participation in undergraduate education seems to decrease with age. For 2020-2021 school year in particular, participation rates in 2541 age range show an increase compared to previous academic years.

In order to examine age-related participation status of the adult students, some age groups in Figure 3 have been classified and this can be seen in Figure 4. Although there is a steady increase in group aged 40 or over each year, it is seen that number of participants shows a decline as age increases (Figure 4). The most frequent age group of adults newly enrolled in undergraduate education is 30-34 years.

Studies on adult educational participation in Turkey are generally conducted in non-formal education institutions. There are not many studies focusing on formal education and center on the adults' profiles. Thus, it has been deemed necessary to carry out a comprehensive investigation examining participation profiles of adults in higher education. To investigate motivations and expectations of adults succeeded in being accepted to same program as a newly graduated student is one of the topics within the concept of adult education and lifelong education that must be scrutinized.

In reports on participation numbers of adult undergraduate students, headings such as detailed demographic characteristics, reasons for return to education, participation barriers,

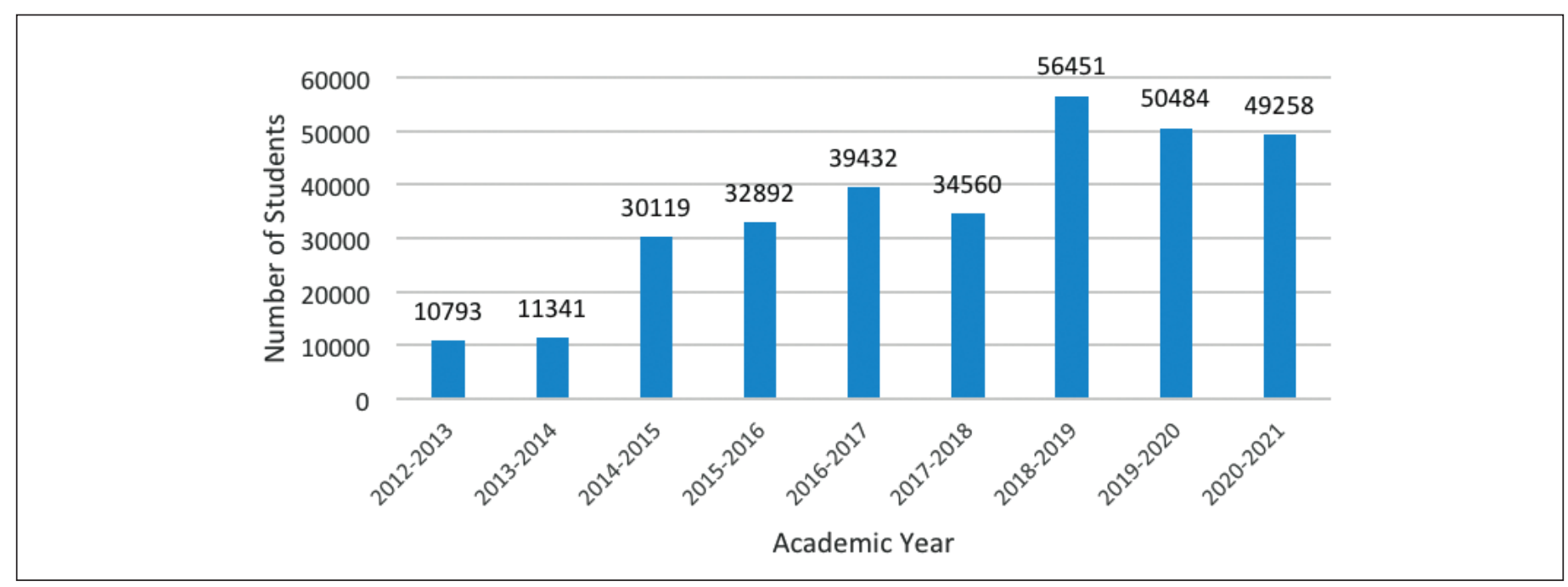

Figure 1: "Adult Students" Participations in Undergraduate Education in Turkey

Source: It was designed via the data available on the YÖK website (YÖK, 2021). 


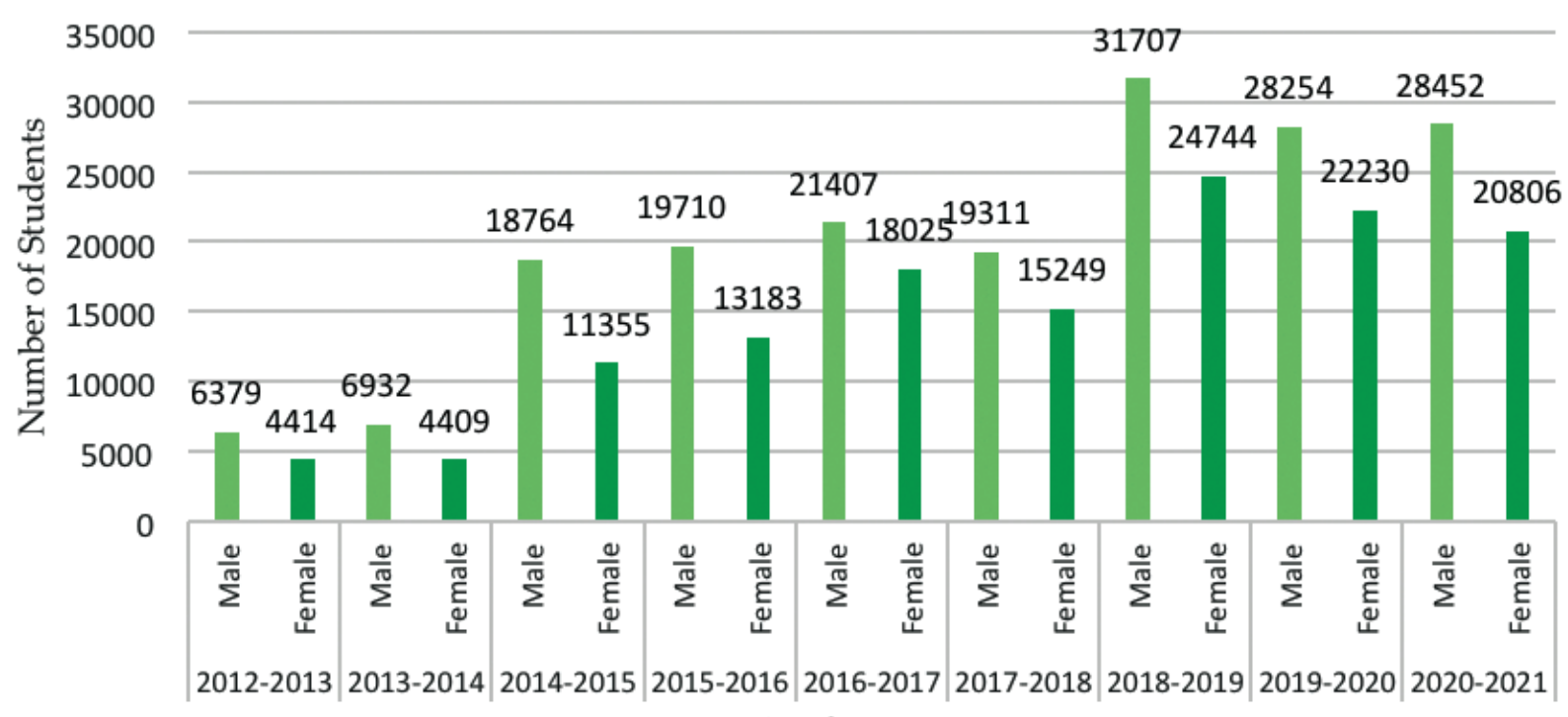

Academic Year

Figure 2: "Adult Students" Participations in Undergraduate Education by Gender in Turkey

Source: It was designed via the data available on the YÖK website (YÖK, 2021).

- 2014-2015

2015-2016

2016-2017

2017-2018

2018-2019

2019-2020

$2020-2021$

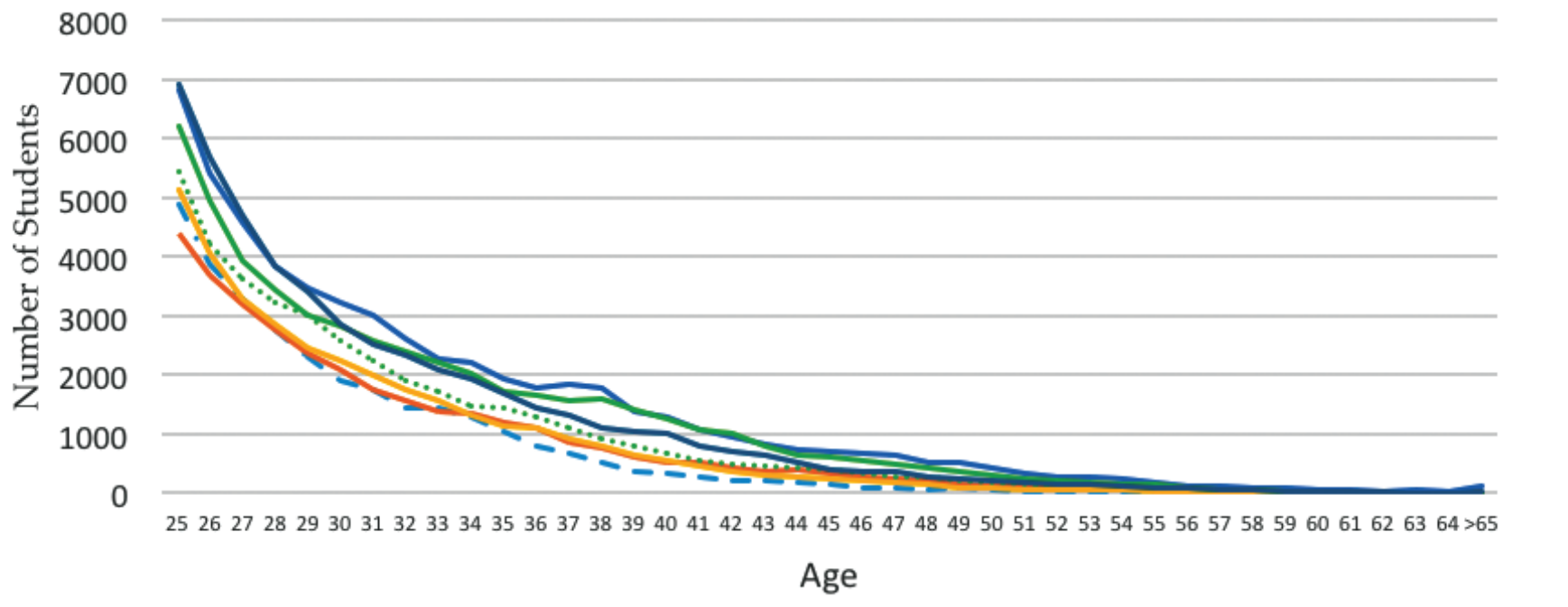

Figure 3: "Adult Students" Participations in Undergraduate Education by Age in Turkey

Source: It was designed via the data available on the YÖK website (YÖK, 2021).

or educational expectations can be found. This study aims to investigate the reasons why individuals deciding to participate in undergraduate education at the age of 25 or over feel their need to add the student role, which will last at least four years, to their already existing roles at home and work. In this framework, for adult students attending structured undergraduate studies:
Research Question 1: What are the demographic characteristics of adult undergraduate students in Turkey?

Research Question 2: What are the educational features of adult undergraduate students in Turkey?

Research Question 3: What are the participation features of adult undergraduate students in Turkey? 


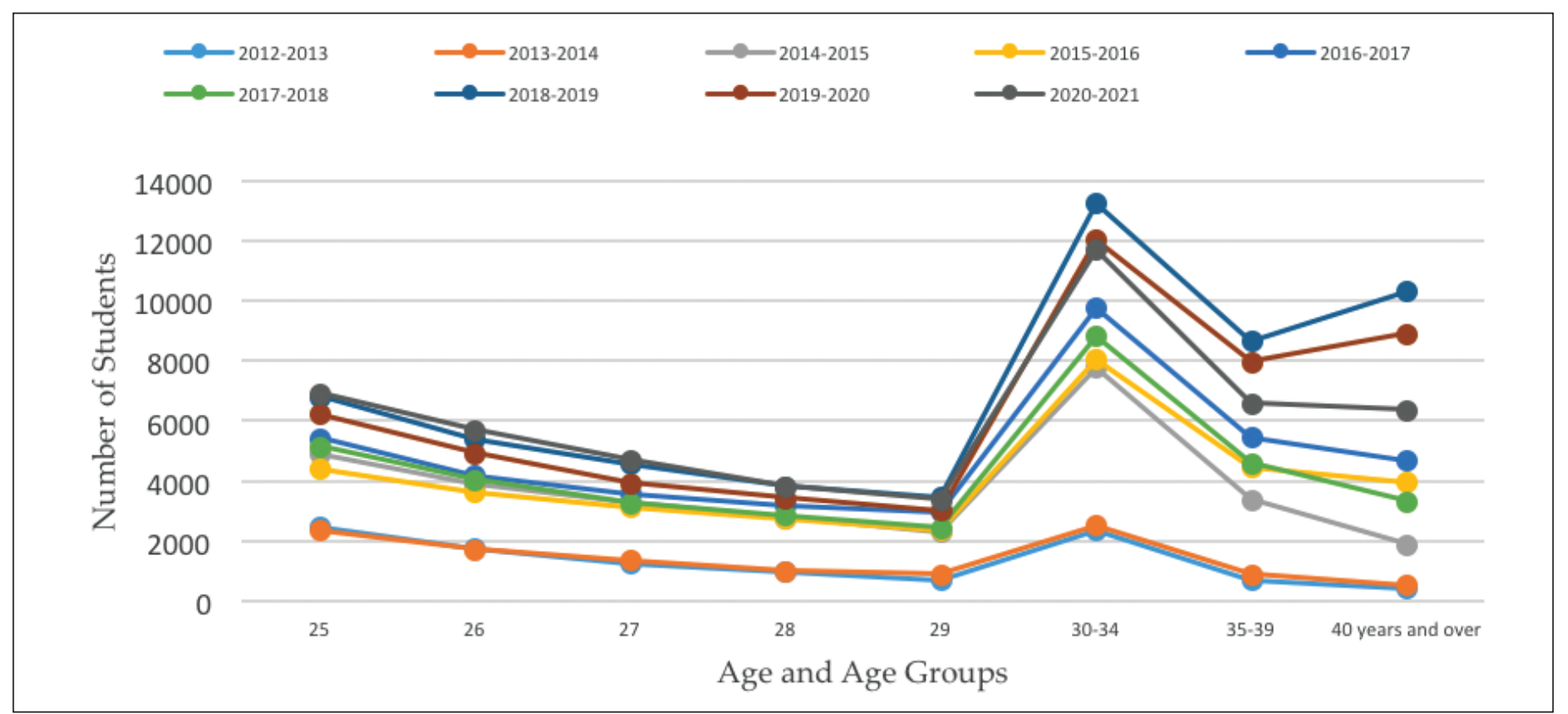

Figure 4: "Adult Students" Participations in Undergraduate Education by Age Groups in Turkey

Source: It was designed via the data available on the YÖK website (YÖK, 2021).

\section{METHOD}

The model of the research is a descriptive study within the survey model which is a very common method in education. In this study, the cross-sectional design type of the survey model was used to examine participation profiles of students started undergraduate education when they were 25 years of age or older. In this type of survey model, researcher collects data at a specific time and in one time. This method has the advantage of providing information about the data in a short term (Creswell, 2012). Descriptive analyses were thus made about the situation.

The necessary administrative permissions have been taken for the collection of data from adult students aged 25 and over. In this context, primarily permission was taken from the Ethics Committee of the University to apply the questionnaire. Secondly, the adult students's name, surname, gender, age, faculty and departmental information were asked from the Student Affairs Office of the university. After all necessary permissions and student information have been received, the process of collecting data has started. The questionnaire forms were given to the volunteer adult students after informing them in the classrooms. Questionnaire forms were applied by taking the permission of the lecturer when the students were in the classes.

Research stage of this study was constituted by 1621 adult students who started their undergraduate education at Süleyman Demirel University (SDU) in Turkey at 25 years or older and were continuing their education as of the 2016-2017 school year. When data was collected, representation of each group was ensured and participants were prevented from accumulating in any certain group by taking the type of settlement, faculty type, program type, style of education and gender into account. Within the scope of the research, valid data was gathered from a total of 472 students compromising 70 programs in 17 Faculties and two Higher Schools. Thus, $1 / 3$ of the universe was reached. The list of adult students was received in excel format and with a closed envelope as computer printout. The data were stored on the researcher's computer only. Data of associate degree students or traditional age students were excluded from the study.

The data collection tool, which will form the basis of the research, has been created by the researchers, with an in-depth literature review on the reasons for participation/dropout of adults, barriers to participation and participation policies. The data collection tool consists of 47 questions, including open and close-ended questions. The draft version of the tool was shared separately with five adult students aged 28, 30, 35, 42 and 57 in different departments. In face-to-face interviews with these adult students, they were asked to examine the data collection tool. Arrangements were made by taking into consideration the suggestions of the students who gave opinions for each question.

Expert opinion was received from seven faculty members, four in the field of Adult Education, one in the field of Scientific Research Methods, one in the field of Computer and Instructional Technologies and one in the field of Education Management and Policy, with regard to the data collection tool. Then the data collection tool was pre-tested with 45 adult students. After the last arrangements were made, the data collection tool was applied.

Analysis of the data collected by quantitative method was interpreted by frequency (f), percent (\%), arithmetic mean, and 
Chi-Square Test of Independence while data collected by and qualitative method was interpreted by content analysis and word cloud.

\section{FINDING and DISCUSSION}

In this section, collected data belonging to study group is grouped according to research questions and presented under three headings; demographic, education and participation/ drop out characteristics.

\section{Demographic Findings}

This section includes gender, age, marital status, employment, monthly income and other findings from demographics information of the participants.

\section{Gender}

$30.30 \%$ of the participants were women and $69.70 \%$ were men In some studies, participation rate of women was higher than that of men (Choy \& Premo, 1995; Graham \& Donaldson, 1999; Rabourn et al., 2015). According to Lin (2016), factors such as lower self-esteem, inadequate family and social support, and more than one social role contribute to adult female students having more stress and anxiety compared to adult male students as well as undergraduate students at traditional age.

It is possible to talk about the increase in participation rates and participation of women in higher education in almost al studies where participation rates are analyzed over the years.

\section{Age}

The participants' ages ranged from 25 to 68, while average age was 32.72 . 70\% of the participants belong to the 25-34 age group. This is consistent with data representing the number of adult students across Turkey (Figure 4). The high participation of active individuals in 25 to 34 year group is a frequent and awaited situation in adult education process. As shown in Figure 5, participation in undergraduate education decreases considerably as age progresses. Age is a decisive factor of participation in adult education. Kyndt, Michielsen, Nooten, Nijs and Baert (2011) stated that participation in training tends to decrease as age increases (especially above 45). They also noted that as adults approach retirement age, they begin to think that education they receive will contribute less to professional progress of their education and that they will not be supported as much as their younger colleagues. The statistics show that there is no significant difference between age and gender categories.

\section{Marital Status}

$49.36 \%$ of participants were married, $47.67 \%$ were single and $2.97 \%$ were divorced or widowed. A significant correlation was found at the level of .05 between gender and marital status ( $p$ $<.05, x^{2}=8,04, \mathrm{Sd}=2$ ).

Compton et al. (2006) have expressed that majority of adult students turn towards higher education as a result of a significant, life-changing process, such as divorce or a career change. In this study, however, only $2.97 \%$ were divorced or widowed. Single women in the study had a higher level of participants than that of married women. This may be attributed to the fact that married women have a larger amount of household responsibilities than single women. However, married men were more likely to participate in undergraduate education than single men. While men are able to continue their education even when they are married, it can be said that married women face more obstacles and difficulties (Tekin, 1988).

\section{Employment}

$35.17 \%$ of the participants were not employed in any job. Almost half of the employed participants were permanent employees in public-private sector. For employees, factors such as terms of employment, salary, seniority and career expectations can be said to be influential in the decision of participation (Kyndt et al., 2011). At the time of enrollment, it had been observed that only $29.45 \%$ of respondents were not working. As such, when employment statuses of participants at the time of enrollment is compared with current employment statuses, it is seen that there has been an increase in the proportion of non-working participants.

For employed participants, their working experience varied between 1 month and 36 years. Average duration of the participants' working experience was calculated to be about 10 years. The most concentrated group was formed by those with between 1 month and 5 years of experience. As a result of the

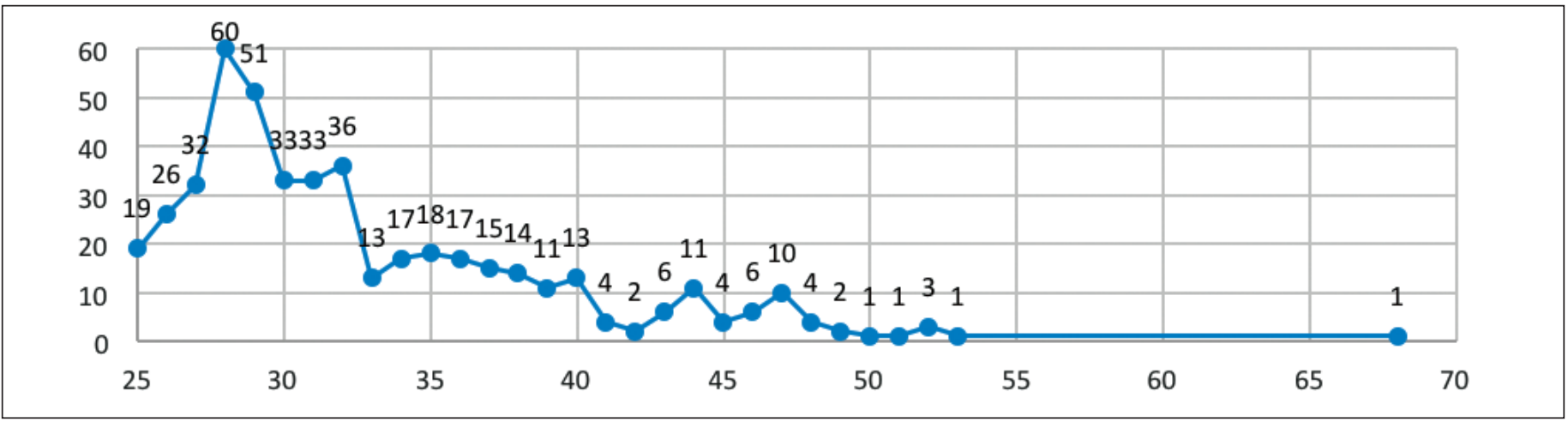

Figure 5: Distribution of participants by age. 
Chi-Square test, a significant correlation was found at the level of .001 between the employment and gender characteristics of the participants $\left(p<.001, x^{2}=57.4, S d=2\right)$.

\section{Monthly Income}

Among those who possessed an income, the highest range was 2501-3500 in Turkish Lira. While $27.36 \%$ of males had no personal income, this rate almost doubled in females at $52.45 \%$. A significant correlation was found at the level of .001 between gender and monthly income level $\left(p<.001, x^{2}=51.6, S d=5\right)$.

\section{Other Findings from Demographics}

As far as household income level, most of the participants had a middle income. $56.99 \%$ of participants stated that they did not have children. The highest rate among the married group was two children.

Based on studies of undergraduate adult students around the world, it can be argued that majority of those who participate are men, young adults over the age of 25 , those who are unmarried, full-time employees, financial independents and those with moderate or high household income (Chao et al., 2007; Kasworm, 2003; Kwang et al., 2004; Morstain \& Smart, 1977).

\section{Findings Related to Education}

This section includes the findings on the level of education before undergraduate education and the type of high school graduated from, faculty, program and the instruction type, placement into universities and other findings from educational background information of the participants.

Level of Education Before Undergraduate Education and Type of High School Graduated From

When the education level data were examined, it was seen that approximately $40 \%$ of the participants were graduated from "general high school". Adult students were found to have "undergraduate education" as their highest level of education before enrolling in undergraduate education. When distribution of education level by sex is examined, it is seen that males are more often undergraduates while female are associate degree graduates.

When the length of time participants took to return to education was examined, it was seen that the longest pause was 33 years. Within all participants, the most frequent period for having taken a break was 0 to 5 years. In this case, it can be said that most of the adults returned to education within a period of a few years after terminating an education process.

\section{Faculty, Program and Instruction Type}

Participants were most concentrated in the Faculty of Engineering, while the highest level of participation was shown in the Zootechnics program. When distribution of participants according to instruction type was examined, it was seen that formal education was the most preferred.

When distribution of adult students according to their working status and education type was examined, it was seen that formal education was preferred by non-employed adults. The group that preferred secondary education and distance education consisted of adults who were employed full time. In this case, unemployed participants who are available during the morning and day, and who do not want to pay tuition are expected to choose primary education.

\section{Placement into Universities}

The way participants settled into university is one of the criteria considered in the research. When settlement patterns were examined, the highest settlement types were observed to be DGS and OSYS (Table 2).

Table 2: Placement Type

\begin{tabular}{l|r|r|}
\hline Placement Type & \multicolumn{1}{|c|}{ f } & \multicolumn{1}{c}{$\%$} \\
\hline Amnesty Laws & 8 & 1.69 \\
\hline DGS & 179 & 37.92 \\
\hline ÖSYS & 173 & 36.65 \\
\hline Engineering Completion Programs & 26 & 5.51 \\
\hline Program to Complete Bachelor in the & 42 & 8.90 \\
Health Field & & \\
\hline Special Ability Exam & 24 & 5.08 \\
\hline Foreign Student Exam & 13 & 2.75 \\
\hline Internal Transfer & 7 & 1.48 \\
\hline Total & $\mathbf{4 7 2}$ & 100 \\
\hline
\end{tabular}

\section{Other Findings from Education}

Participants were asked about their graduation expectations of the program they had chosen. More than half stated that they expected to graduate from the program on time. When this statement is taken as a whole, about a third of the group believed that they would leave program halfway through, or would not be able to complete it in time. This situation may be related to participation barriers that research has found. Allen (1993) argued that institutions should be alert to specific problems of nontraditional students who are at risk of leaving school and employ competent advisors and well-educated staff. Harkins (2009) emphasized that, besides increasing attendance, it is also important issue to support permanence of adults in institutions.

When asked about their plans for future education, more than half of the participants indicated that they would continue their education, while some adults stated that they would not be involved in a new educational activity after their undergraduate studies. When the group having plans to continue was asked about their future educational goals, more than half said they would continue their education with a postgraduate degree.

\section{Findings Related to Reasons for Participation/Drop Out}

This section includes the findings on previous undergraduate education experiences, reasons for drop out, relations between completed and continued programs, reasons for partic- 
ipation, reasons for not participating, barriers faced by adults while continuing their education, reasons for choosing the program, higher education policies, other findings according to participation/drop out characteristics and "final words" of the participants. In the collection and analysis of the data, expressions have been used for each question and analyzes have been made by theming all these expressions. For example, 22 statements given for reasons of participation have been collected under 5 themes such as "Professional Reasons", "Economic Reasons", "Social Reasons", "Personal Reasons" and "Academic Reasons".

\section{Previous Undergraduate Education Experiences}

In this section, detailed reviews of previous (if existing) and current undergraduate education of adults were made first. When examining Table 3 to see which kind of higher education process participants went through, it is seen that "I graduated from a previous undergraduate program and this is my $2^{\text {nd }}$ undergraduate program" statement is marked most often.

Table 3: Previous Undergraduate Experience

\begin{tabular}{|c|c|c|}
\hline Undergraduate Experience & f & $\%$ \\
\hline I returned with an amnesty law & 5 & 1.06 \\
\hline This is my first undergraduate program & 193 & 40.89 \\
\hline $\begin{array}{l}\text { I graduated from a previous undergraduate } \\
\text { program and this is my } 2^{\text {nd }} \text { undergraduate } \\
\text { program }\end{array}$ & 203 & 43.01 \\
\hline $\begin{array}{l}\text { I dropped out an undergraduate program } \\
\text { before I finished it. This is different than I } \\
\text { left. }\end{array}$ & 60 & 12.71 \\
\hline Others & 11 & 2.33 \\
\hline Total & 472 & 100 \\
\hline
\end{tabular}

Table 4 summarizing situations of participants, indicates the participants who are students in their first undergraduate program and those continuing their $2^{\text {nd }}$ or $3^{\text {rd }}$ undergraduate education. The number of the participants stating the "this is my first undergraduate program" expression in Table 4 also includes those who started an undergraduate education but dropped out later.

Table 4: Previous Undergraduate Experience Summary

\begin{tabular}{|l|c|c|}
\hline Undergraduate Experience & f & $\%$ \\
\hline This is my first undergraduate program & 258 & 54.66 \\
\hline This is my $2^{\text {nd }} / 3^{\text {rd }}$ undergraduate program & 214 & 45.34 \\
\hline Total & $\mathbf{4 7 2}$ & $\mathbf{1 0 0}$ \\
\hline
\end{tabular}

\section{Reasons for Drop Out}

The data in Table 3 shows that some participants had either taken a break from their previous undergraduate education or drop out the program without completing their education.
When reasons for leaving were examined for this group, which constituted $14.83 \%$ of all participants (70 people), the reason given most frequently was "financial reasons" and given most rarely was "being expelled". Allen (1993) stated that arrangements made by institution will influence students' decisions to continue. He argued that students should not be pressured to continue with programs they are unsatisfied; persuasion to continue must be initiated before student has made the decision to leave school. Bean (1980) mentions that this decision to leave education should not always be considered negatively; it may have been the right choice under those circumstances.

\section{Relations Between Completed and Continued Programs}

214 of participants had a previous undergraduate education. These students were asked about the type of education and the name of the program they completed. As a result of the analyses, it was seen that 208 of the adults were embarking on their second undergraduate program while 6 of them were on their third program. Adult students were found to gravitate towards both different and similar areas compared to their past choices (Table 5).

\section{Reasons for Participation}

Since participation in adult education is a voluntary process, it is important to understand reasons for participation (Merriam, Caffarella and Baumgartner, 2007). At the same time, findings obtained about those participating in adult education activities and for what reasons should be followed closely by both service providers and policy makers.

In order to make analyses within the study, statements have been grouped into "Professional Causes", "Economic Causes", "Social Causes", "Personal Causes" and "Academic Causes". When asked primary reason for continuing their undergraduate education, about $70 \%$ of the participants chose the statement "to advance to a better position in my profession" in the "Professional Causes" category. Men, those who were married, employed, and those with moderate income tended to choose "Professional Causes"; women, those who were single and unemployed, and individuals who possessed either low or high-income tended to choose "Academic Causes".

\section{Reasons for Not Participating}

Adult students' reasons for participation do not give any insight on those who do not participate. It is misleading to believe that those who do not participate are happy with their work, and have a satisfying time with their families, communities and leisure activities (Merriam and Caffarella, 2001). For this reason, researchers are additionally concerned with the reasons why adults do not participate.

In order to for analyses to be made as to why adults do not participate, statements have been grouped into "Professional Causes", "Personal Causes", "Domestic Causes", and "Academic Causes", and "Corporate Causes". Currently, the most frequent reason for not participating is the statement "I did not pass the exam" in "Academic Cause". Men, middle-aged individuals, employees, and those who are married often state that they 
Table 5: Completed Program and Continued Program Examples of Some Participants

\begin{tabular}{|l|c|c|c|c|}
\hline Previous Field Type & Completed Program & Current Field Type & Continued Program & Statement of Changes \\
\hline Numerical Score & Medical Faculty & Numerical Score & $\begin{array}{c}\text { Mechatronics } \\
\text { Engineering }\end{array}$ & Similar \\
\hline Numerical Score & Civil Engineering & Equiponderant Score & Law School & Different \\
\hline Verbal Score & Sociology & Verbal Score & Philosophy & Similar \\
\hline Equiponderant Score & Business & Numerical Score & Mechanical Engineering & Different \\
\hline
\end{tabular}

do not participate in education due to "Professional Causes". On the other hand, women, younger individuals, and those who are single and unemployed have stated that they cannot attend due to "Academic Causes".

\section{Barriers Faced by Adults While Continuing Their Education}

Adults must be willing and successful in learning activities to maintain their motivation for learning (Wlodkowski, 2008). However, traditional structure of higher education creates obstacles for adults seeking education in terms of continuance and success (Chao et al., 2007). In this context, knowing the difficulties that adults face in education process will help to improve their policies and practices. In order to be able to analyze the barriers to participation, the statements have been grouped as "Situational Barriers", "Institutional Barriers" and "Dispositional Barriers", as in Cross's classification (1981'den akt: Boeren, 2009). Institutional barriers typically stem from the inadequacy of the program; energy and hours spent on bureaucratic procedures during enrollment; financial issues; deficient support services; and institutional and educational practices such as the fact that program planning and entrance conditions are not generally suitable for adults. Situational barriers include obstacles resulting from the person's living situation, such as home and work responsibilities, time constraints, and child care needs. Dispositional barriers concern perception and attitude of students about themselves.

The most important item marked most often in participation obstacles was the statement "Mandatory attendance is straining for me" in Institutional Barriers. While "Institutional Barriers" ranked first for young adults, those who were unmarried and possessed a low-income, "Institutional Barriers" were the primary barriers for elderly people, those who were married, permanent employees, and possessed high income.

\section{Reasons for Choosing the Program}

Independent from their reasons for participating in undergraduate education, adults were asked their reasons for choosing their program. To be able to make analyses according to the specific reason, expressions were grouped as "Occupational Preferences", "Academic Preferences", "Personal Preferences", and "Institutional Preferences". The most frequently given reason was "my interest in this department". The personal reasons motivating adults to participate in education can be triggered by internal or external motivation. However, with the result of this study, it can be said that adults often continue their education depending on internal motivation and accordingly choose a field in which they are more interested. The findings of the current study is similar to those obtained by Elliot and Brna (2009), Harkins (2009) and Singh (2014).

In all groups and in the first and second education, it was seen that programs were chosen according to "Personal Preferences". Those who chose distance education were more likely to do so because of "Corporate Causes" and "Professional Causes". Importance given to educational technologies by States and investments made in this context are important elements to increase participation of adults in undergraduate programs. Higher education institutions can benefit from distance education and advanced information and communication technologies applications that save individuals from dependency on time and space. For full-time employed adult learners of advanced age, being able to study and participate in programs whenever they want is of prime importance (Choy and Premo, 1995; Jung and Cervero, 2002). For this reason, most full-time adult students prefer distance education as it is a system that at least does not have mandatory attendance.

\section{Higher Education Policies That Can Be Developed}

Higher education institutions are more likely to conduct studies that bring traditional-age students to the foreground (Sissel, Hansman and Kasworm, 2001). In addition to the attitude and behavior of lecturers, administrators, and support staff, the policies and procedures of these institutions, do not take adult students into view and do not consider complexity of adult life. This situation may sometimes frustrate adults or cause them to lose heart (Kasworm, 2008). Most university institutions do not realize that a section of their students are midde-aged, married and employed (Sissel et al., 2001). However, when looking at population projections, it is inevitable that universities will begin to focus on middle-aged students rather than traditional-age students.

To make better analyses within the scope of the study, expressions have been grouped as "Introduction, Continuation and Time Regulations", "Crediting Experience", "Financial Support Policies" and "Educational Support Services". Participants have been asked to choose the most important one they believed out of higher education policies that could be developed to solve obstacles they faced during their education. The largest ratio of participants chose the statement "attendance should not be compulsory". When the role of being a student is added to home, work and family responsibilities, adults can only participate in limited lesson time (Aruğaslan and Uysal, 2017). While participants from all ages and all marital status, perma- 
nent employees, and middle and high income group chose policies on "Entry, Continuation and Time Regulations"; unemployed or temporary workers and those with low-income chose "Economic Support Policies".

\section{Other Findings According to Participation/Drop Out Characteristics}

Participants were found to be their own biggest supporters in education. Their families and social circles came next. It was seen that $85 \%$ of participants did not participate in social activities while $46 \%$ did not spend any time on campus outside of class. When attitudes of course advisors towards adult students were examined, $53 \%$ of them were found to be aware. Most of the participants were not found to apply for financial aid. When adults who both worked and studied were asked the question "work or education?", 74\% stated that their work came first.

\section{"Final Words" Content Analysis and Word Cloud}

Participants have been asked to say their final words with one open-ended question. Thoughts of 139 participants have been given in this section. The analysis in this section consists of these final words. Opinions of participants in the final words section been examined in two different ways. The first one is the content analysis while the other is word cloud. Categories, themes and sub themes arisen from the content analysis are as shown in Table 6. 68.35\% of respondents expressed their views on "Expectations and Needs", 45.32\% on "Participation Barriers" and $16.55 \%$ on "Participation Motivations".

The words written in the word cloud section with the highest frequency were those such as "education" (eğitim), "attendance" (devam), "adult" (yetişkin), "job” (iş), "class" (ders), "age" (yaş), "employee" (çalışan), "student" (öğrenci), "survey" (anket), and "higher education" (yükseköğretim) (Figure 6).

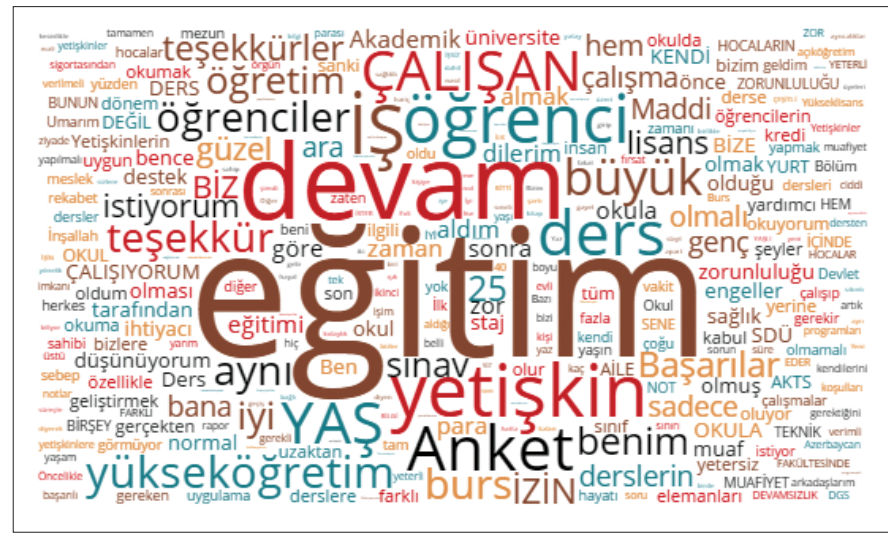

Figure 6: "Final Words" in word cloud

Words with a high frequency in the word cloud were found to be those associated with expressions used most frequently for participation barriers and developmental policies (Table 7).

\section{CONCLUSION and RECOMMENDATIONS}

This study aims to examine the participation profiles of adults aged 25 and over, who are considered outside the traditional education age, and decide to take formal undergraduate education for the first time or again. In this context, higher education policies and practices developed for adult students around the world and in Turkey have been examined first. Then, the demographic, educational and participation/leaving characteristics of adult undergraduate students who started their education at the faculties and high schools of Süleyman Demirel University when they were 25 years old and over were analyzed in detail.

In this research which was carried out for the undergraduate education of adults, the subjects that were investigated in detail were the reasons for participation, reasons for not participating, barriers to participation, reasons for choosing the pro-

Table 6: Categories, Themes and Sub Themes

\begin{tabular}{|c|c|c|c|c|}
\hline Category & Theme & Sub Theme & f & $\%$ \\
\hline \multirow{5}{*}{$\begin{array}{l}\text { Expectations and } \\
\text { Needs }(68.35 \%)\end{array}$} & \multirow{3}{*}{ Encourage Policies } & Employment oriented expectations & 1 & 0.72 \\
\hline & & Employer support & 1 & 0.72 \\
\hline & & State support & 3 & 2.16 \\
\hline & Health Care Service & Health insurance support & 3 & 2.16 \\
\hline & Institutional Expectations & $\begin{array}{l}\text { Adult friendly learning environments } \\
\text { Accommodation services }\end{array}$ & $\begin{array}{r}86 \\
1\end{array}$ & $\begin{array}{r}61.87 \\
0.72\end{array}$ \\
\hline \multirow{3}{*}{$\begin{array}{l}\text { Participation Barriers } \\
(45.32 \%)\end{array}$} & Professional Barriers & Status of working adults & 12 & 8.63 \\
\hline & Prejudices Towards Adults & $\begin{array}{l}\text { Prejudices of traditional students } \\
\text { Prejudices of academic staff }\end{array}$ & $\begin{array}{r}4 \\
23\end{array}$ & $\begin{array}{r}2.88 \\
16.55\end{array}$ \\
\hline & Financial Obstacle & $\begin{array}{c}\text { Financial Support } \\
\text { Shelter } \\
\text { Tuition }\end{array}$ & $\begin{array}{r}20 \\
3 \\
1\end{array}$ & $\begin{array}{r}14.39 \\
2.16 \\
0.72\end{array}$ \\
\hline $\begin{array}{l}\text { Participation } \\
\text { Motivations (16.55\%) }\end{array}$ & Orientations & $\begin{array}{c}\text { Goal-Oriented } \\
\text { Learning-Oriented }\end{array}$ & $\begin{array}{r}15 \\
8\end{array}$ & $\begin{array}{r}10.79 \\
5.76\end{array}$ \\
\hline
\end{tabular}


Table 7: Relationship Between Some Word Cloud Result and Some Study Findings

\begin{tabular}{l|l|l} 
High Frequency Word & Participation Barriers & Developable Policies \\
\hline Attendance & "Mandatory attendance is straining for me." & "Attendance should not be compulsory" \\
Job, employee etc. & "Professional density is getting most of my time." & $\begin{array}{l}\text { "Employed adults must be legally allowed from } \\
\text { workplaces" }\end{array}$
\end{tabular}

gram, and improvable higher education policies. This research reveals that adult students who decide to take formal undergraduate education at the age of 25 and above have different reasons for participation, they face many obstacles while continuing their education. Therefore, it is necessary to develop higher education policies that will include adult students as well as traditional age students.

Adult students in higher education are a growing population with unique needs. However, it is known that many are forced to leave school because of numerous obstacles and practices. Understanding and solving various obstacles faced by them will encourage further decisions to continue education. Hence, suggestions emerging as a result of this research can be listed as follows:

- Higher education policies that are inclusive of adults should be developed,

- Practices should be developed in order to make entrance into higher education easier for adult students,

- Adults should also be considered in the supply of academic and administrative support,

- Services ensuring continuance of education should be developed,

- Integration activities should be included within the campus,

- Regulations should be made to reduce obstacles for participation,

- Unemployed adults should be provided with financial aid,

- It should be necessary to offer lifelong learning as a part of as required courses in educational schools and as a part of elective courses in other higher education institutions.

\section{REFERENCES}

Allen, B. A. (1993). The student in higher education: Nontraditional student retention. Community Services Catalyst, 23(3), 19-22.

Aruğaslan, E., \& Uysal, M. (2017). Yükseköğretim'de Yetişkin Öğrencilere Yönelik Politikalar.Journal of Research in Educational and Teaching, 6(2), 1-13.

Banks, J. (2010). Female nontraditional students in higher education (Unpublished doctoral dissertation). Indiana University, Indiana.

Bean, J. P. (1980). Dropouts and turnover: The synthesis and test of a causal model of student attrition. Research in Higher Education, 12(2), 155-187. doi:10.1007/BF00976194
Bengo, N. M. A. (2020) Managing Instructional Strategies in Classrooms With Adult Learners, The Journal of Continuing Higher Education, 68(2), 71-83, doi: 10.1080/07377363.2020.1712578

Berker, A., \& Horn, L. (2003). Work first, study second: Adult undergraduates who combine employment and postsecondary enrollment. Retrieved from https://nces.ed.gov/ pubs2003/2003167.pdf

Boeren, E. (2009). Adult education participation: The Matthew principle. Filosofija- Sociologija, 20(2), 154-161.

Boeren, E., Holford, J., Nicaise, I. \& Baert, H. (2012). Why do adults learn? Developing a motivational typology across 12 European countries. Globalisation, Societies and Education, 10(2), 247269. doi:10.1080/14767724.2012.678764

Broek, S., \& Hake, B. J. (2012). Increasing participation of adults in higher education: Factors for successful policies. International Journal of Lifelong Education, 31(4), 397-417. doi:10.1080/02 601370.2012.663801

Bundy, A. P., \& Smith, T. B. (2004). Introduction to the special section-breaking with tradition: Effective counseling services for nontraditional students. Journal of College Counseling, 7(1), 3-4. doi: 10.1002/j.2161-1882.2004.tb00252.x

Bye, D., Pushkar, D., \& Conway, M. (2007). Motivation, interest, and positive affect in traditional and nontraditional undergraduate students. Adult Education Quarterly, 57(2), 141-158.

CAEL. (1999). Serving adult learners in higher education. Retrieved from https://www.carrollcc.edu/uploadedFiles/CarrollCCedu/ Content/PDF/Documents/PTA/Summary\%20of\%20Alfi\%20 Principles\%20of\%20Effectiveness.pdf

Caruth, G. D. (2013). Andragogy in higher education: Identifying 2010 adult learners in baccalaureate degree-granting institutions (Unpublished doctoral dissertation). Texas A\&M University-Commerce, Commerce.

Chao, E. L., DeRocco, E. S., \& Flynn, M. K. (2007). Adult learners in higher education barriers to success and strategies to improve results. Retrieved from https://files.eric.ed.gov/fulltext/ ED497801.pdf

Choy, S. P., \& Premo, M. D. (1995). Profile of older undergraduates: 1989-90. Retrieved from https://nces.ed.gov/pubs95/95167. pdf

Compton, J. I., Cox, E., \& Laanan, F. S. (2006). Adult learners in transition. New Directions for Student Services, 2006(114), 73-80. doi:10.1002/ss.208

Coulter, X., \& Mandell, A. (2012). Adult higher education: Are we moving in the wrong direction? The Journal of Continuing Higher Education, 60(1), 40-42. doi:10.1080/07377363.2012. 649133

Creighton, S. \& Hodson, L. (2002). Participation trends and patterns in adult education: 1991 to 1999. Retrieved from https://nces. ed.gov/pubs2002/2002119.pdf 
Creswell, J. W. (2012). Educational research: Planning, conducting, and evaluating quantitative and qualitative research (4th ed.). Boston, MA: Pearson.

DiSilvestro, F. R. (2013). Continuing higher education and older adults: A growing challenge and golden opportunity. New Directions for Adult and Continuing Education, 2013(140), 7987. doi:10.1002/ace.20076

Donaldson, J. F., \& Townsend, B. K. (2007). Higher education journals' discourse about adult undergraduate students. The Journal of Higher Education, 78(1), 27-50. doi:10.1353/ jhe.2007.0001

Elliot, D. L., \& Brna, P. (2009). 'I cannot study far from home': non-traditional learners' participation in degree education. Journal of Further and Higher Education, 33(2), 105-117. doi:10.1080/03098770902856645

Eurydice. (2000). Lifelong learning: The contribution of education systems in the Member States of the European Union. Retrieved from http://edz.bib.uni-mannheim.de/daten/edzwf/eud/00/2-87116-294-8-EN.pdf

Eurydice. (2011). Adults in formal education: Policies and practice in Europe. Retrieved from http://eacea.ec.europa.eu/education/ eurydice/documents/thematic_reports/128EN.pdf.

Fairchild, E. E. (2003). Multiple roles of adult learners. New Directions for Student Service,2003(102), 11-16. doi:10.1002/ ss.84

Firstpost. (2016). Never too old for school: At 96, man from Japan becomes oldest university graduate. Retrieved June 6, 2021 from https://www.firstpost.com/world/never-too-old-forschool-at-96-man-from-japan-becomes-oldest-universitygraduate-2818066.html

Grabowski, S. M. (1972). Motivational Factors of Adult Learners in a Directed Self-Study Bachelor's Degree Program (Unpublished doctoral dissertation). Syracuse Üniversitesi, New York.

Graham, S., \& Donaldson, J. F. (1999). Adult students' academic and intellectual development in college. Adult Education Quarterly, 49(3), 147-161.

Harkins, P. M. (2009). The experience of nontraditional students enrolled in a transitions course in an undergraduate program (Unpublished doctoral dissertation). University of Connecticut, United States.

Hefler, G., \& Markowitsch, J. (2010). Formal adult learning and working in Europe: A new typology of participation patterns. Journal of Workplace Learning, 22(1/2), 79-93. doi:10.1108/13665621011012870

Johnstone, J. W. C. (1963). Volunteers for learning A study of the educational pursuits of American adults. Chicago: National Opinion Research Center, University of Chicago.

Jung, J. C., \& Cervero, R. (2002). The social, economic and political contexts of adults' participation in undergraduate programmes: a state-level analysis. International Journal of Lifelong Education, 21(4), 305-320. doi:10.1080/02601370210140977

Kasworm, C. E. (1990). Adult undergraduates in higher education: A review of past research perspectives. Review of Educational Research, 60(3), 345-372. doi:10.3102/00346543060003345

Kasworm, C. E. (2003). Setting the stage: Adults in higher education. New Directions for Student Services, 2003(102), 3-10. doi:10.1002/ss.83
Kasworm, C. E. (2008). Emotional challenges of adult learners in higher education. New Directions for Adult and Continuing Education, 2008(120), 27-34. doi:10.1002/ace.313

Kasworm, C. E. (2010). Adult learners in a research university: Negotiating undergraduate student identity. Adult Education Quarterly, 60(2), 143-160. doi:10.1177/0741713609336110

Kaya, H. E. (2010). Avrupa Birliği yaşam boyu öğrenme ve yetişkin eğitimi politikaları (Unpublished doctoral dissertation). Ankara Üniversitesi, Ankara.

Kwang, K., Hagedorn, M. C., Williamson, J., \& Chapman, C. (2004). Participation in adult education and lifelong learning: 2000-01. Retrieved from https://nces.ed.gov/pubs2004/2004050.pdf

Kwong, T. M., Mok, Y. F., \& Kwong, M. L. (1997). Social factors and adult learners' motivations in re-entering higher education. International Journal of Lifelong Education, 16(6), 518-534. doi:10.1080/0260137970160605

Kyndt, E., Michielsen, M., Nooten, L. V., Nijs, S., \& Baert, H. (2011). Learning in the second half of the career: stimulating and prohibiting reasons for participation in formal learning activities. International Journal of Lifelong Education, 30(5), 681-699. doi:10.1080/02601370.2011.611905

Lake, E. D., \& Pushchak, A. J. (2007). Better allocating university resources to create on-line learning environments for nontraditional students in underserved rural areas. Innovative Higher Education, 31(4), 215-225. doi:10.1007/s10755-0069025-5

Lin, X. (2016). Barriers and challenges of female adult students enrolled in higher education: A literature review. Higher Education Studies, 6(2), 119-126. doi:10.5539/hes.v6n2p119

Lopuch, V. S. (2015). The new campus landscape: A narrative study of non-traditional undergraduates' identity construction while enrolled at a traditional private college (Unpublished doctoral dissertation). Northeastern University, Boston.

Malhotra, N. K. (1997). Perceived situational, institutional, and dispositional participation barriers to undergraduate education for nontraditional adult learners at a small, tuitiondriven private collage (Unpublished doctoral dissertation). University of South Florida, Florida.

McAllister, C. (2010). "This is the beginning of my life educationally": older (50+ years) working class adults' participation in higher education in Scotland, through the lens of critical educational gerontology. International Journal of Lifelong Education, 29(5), 547-563. doi:10.1080/02601370.2010.512802

Memurlar.Net. (2020). Profesör ders verdigi fakültede ogrenci oldu. Retrieved June 05, 2021, https://video.memurlar.net/ video/68332/profesor-ders-verdigi-fakultede-ogrenci-oldu. html

Merriam, S. B., \& Caffarella, R. S. (2001). Participation in adult education. In S. B. Merriam, C. R.S., R. J. Wlodkowski, \& P. Cranton (Eds.), Adult learning theories, principles and applications. John Wiley \& Sons, INC.

Merriam, S. B., Caffarella, R. S. \& Baumgartner, L. (2007). Learning in adulthood: A comprehensive guide (3rd ed). San Francisco: Jossey-Bass.

Morstain, B. R., \& Smart, J. C. (1977). A motivational typology of adult learners. The Journal of Higher Education, 48(6), 665679. doi: 10.1080/00221546.1977.11776584 
Myers, K., Conte, N. \& Rubenson, K. (2014). Adult learning typology: Adult learning and returns to training project. Social Research and Demonstration Corporation. Ottawa, Ontario.

Pollard, E. (2008). University is not just for young people. Institute for Employment Studies DIUS Research Report. Brighton.

Postan, L. (2014). Adult education and some andragogical dimensions of higher education in the Republic of Moldova. Procedia - Social and Behavioral Sciences, 142, 127-132. doi:10.1016/j.sbspro.2014.07.621

Prins, E., Kassab, C., \& Campbell, K. (2015). Adult learners in higher education: A rural-urban analysis of Pennsylvania FAFSA applicants' educational, demographic, and financial characteristics. The Journal of Continuing Higher Education, 63(2), 71-85. doi:10.1080/07377363.2015.1042999

Rabourn, K. E., Shoup, R. \& Brckalorenz, A. (2015, May). Proceedings from Annual Forum of the Association for Institutional Research: Barriers in Returning to Learning: Engagement and Support of Adult Learners. Denver: Colorado.

Roddy, S. (2005). Adults returning to collage (Unpublished doctoral dissertation). University Of Oklahoma, Oklahoma.

Saar, E., Vöörmann, R., \& Lang, A. (2014). Employers' support for adult higher education students in liberal post-socialist contexts. International Journal of Lifelong Education, 33(5), 587-606. doi:10.1080/02601370.2014.945624

Santos, D., Miguel, L. (2020). The Motivation and Experience of Distance Learning Engineering Programmes Students: A Study of Non-Traditional, Returning, Evening, and Adult Students. International Journal of Education and Practice, 8(1), p134148.

Schuetze, H. G., \& Slowey, M. (2002). Participation and exclusion: A comparative analysis of non-traditional students and lifelong learners in higher education. Higher Education, 44(3-4), 309327. doi:10.1023/A:1019898114335
Singh, A. K. (2014). Non-traditional students' quest for higher education: Personal and environmental challenges in a rural community college (Unpublished doctoral dissertation). Wilmington University, New Castle.

Sissel, P. A., Hansman, C. A., \& Kasworm, C. E. (2001). The politics of neglect: Adult learners in higher education. New Directions for Adult and Continuing Education, 2001(91), 17-28. doi:10.1002/ace.27

Stein, D. S., Wanstreet, C., \& Trinko, L. A. (2011). From consideration to commitment: Factors in adults' decisions to enroll in a higher education degree program. The Journal of Continuing Higher Education, 59(2), 68-76. doi:10.1080/07377363.2011 .568820

Tekin, M. (1988). Ankara ilinde yetişkinleri örgün yetişkin eğitimi programlarına katılmaya güdüleyen etmenler ve yetişkinlerin katılmada karşılaştıkları güçlükler (Unpublished doctoral dissertation). Ankara Üniversitesi, Ankara.

Venegas-Muggli, J. I. (2020). Higher education dropout of nontraditional mature freshmen: the role of sociodemographic characteristics, Studies in Continuing Education, 42(3), 316332, doi: 10.1080/0158037X.2019.1652157

Wallace, J. R. (1989). A study of nontraditional-aged undergraduate student enrollment at selected colleges and universities in California (Unpublished doctoral dissertation). United States International University, San Diego.

Wlodkowski, R. J. (2008). Enhancing adult motivation to learn: A comprehensive guide for teaching all adults (3rd ed.). San Francisco: Jossey-Bass: A Wiley Imprint.

YÖK. (2017). Öğrenci afları (6111 ve 6353 sayılı kanunun uygulamaları). Retrieved from http://www.yok.gov.tr/

YÖK. (2021). Yükseköğretim Bilgi Yönetim Sistemi. Retrieved May 27, 2021, from http:// https://istatistik.yok.gov.tr/ 